\title{
Effect of summer pruning on some fruit quality traits in Hayward kiwifruit
}

Gregorio Gullo ${ }^{1 *}$, Valentino BrancA ${ }^{1}$, Agostino DATTOLA ${ }^{1}$, Rocco ZAPPIA $^{1}$, Paolo INGLeSE ${ }^{2}$

${ }^{1}$ Dep. AG.R.A.R.I.A., Univ. Reggio Calabria, Feo di Vito, 89124 Reggio Calabria, Italy, ggullo@unirc.it

2 Dep. Agric For Sci, Univ. Palermo,

Viale delle Scienze, 90128 Palermo, Italy

${ }^{*}$ Correspondence and reprints

Received 2 July 2012 Accepted 15 September 2012

Fruits, 2013, vol. 68, p. 315-322 (C) 2013 Cirad/EDP Sciences All rights reserved DOI: $10.1051 /$ fruits/2013077 www.fruits-journal.org

RESUMEN EsPañol, p. 322

\section{Effect of summer pruning on some fruit quality traits in Hayward kiwifruit.}

Abstract - Introduction. The aim of our study was to analyze the effect of various levels of light availability in the fruit microenvironment (induced by summer pruning) on some fruit quality traits. Materials and methods. Two levels of summer pruning were set: removal of either 30\% or $60 \%$ of the canopy leaf area. These treatments were compared with the control (unpruned vines). Two canopy layers (upper and lower) were identified in each treatment and in the control vines. At harvest, yield per cane and per shoot was recorded in the two canopy layers; fruit fresh weight, flesh firmness, total soluble solid content and total titratable acidity were measured. Fruit Total Antioxidant Capacity (TAC) and Total Polyphenols (TPH) were determined at kiwifruit harvest and post-harvest ( 60 days after storage at $1{ }^{\circ} \mathrm{C}$ ) in relation to their position within the canopy (layer) and to the pruning treatment applied. Results. Removing 60\% of the canopy leaf area induced higher titratable acidity and flesh firmness of kiwifruits at harvest; it reduced fruit weight and crop yield, but increased TAC and TPH compared with kiwifruits of control. Removing 30\% leaf area did not reduce mean fruit weight and crop yield; it increased TAC and TPH at harvest by $20 \%$. Post-harvest TAC and TPH evolution did not differ among treatments. Discussion and conclusion. Pergola-trained kiwifruit vines showed good performances in terms of crop yield and fruit quality when summer pruning reduced the Leaf Area Index (LAI) to 3. More intense pruning resulted in a significant increase in fruit TAC, but reduced fruit weight and crop yield, and delayed softening of pulp.

Italy / Actinidia deliciosa / cultivation / defoliation / leaf area index / fruits / quality / antioxidants / polyphenols

\section{Effet de la taille d'été sur certains caractères composant la qualité de kiwis} de la variété Hayward.

Résumé - Introduction. Le but de notre étude a été d'analyser les effets, sur certains caractères de la qualité des kiwis, de différents niveaux de disponibilité de la lumière dans le microenvironnement des fruits. Ces différents niveaux de disponibilité de la lumière ont été induits par une taille d'été plus ou moins sévère. Matériel et méthodes. Deux niveaux de taille d'été ont été appliqués : la suppression de soit $30 \%$, soit $60 \%$ de la surface foliaire de la canopée. Ces traitements ont été comparés avec un traitement témoin de lianes non taillées. Deux couches de la canopée (supérieure et inférieure) ont été distinguées pour chacun des deux traitements et pour les lianes témoins. A la récolte, le rendement par canne et par tige a été enregistré pour chacune de ces deux couches de la canopée ; le poids frais des fruits, la fermeté de la pulpe, la teneur totale en solides solubles et l'acidité titrable totale ont été mesurés. La capacité antioxydante totale (CAT) et les polyphénols totaux (PHT) du fruit ont été déterminés à la récolte des kiwis et après 60 jours de stockage à $1{ }^{\circ} \mathrm{C}$; ces paramètres ont été étudiés en fonction de leur position au sein de canopée (couche) et du traitement d'élagage qui avait été appliqué à la liane. Résultats. La suppression de $60 \%$ de la surface foliaire du couvert a induit une plus forte acidité titrable et plus de fermeté de la pulpe des kiwis à la récolte ; elle a réduit le poids des fruits et le rendement des cultures, mais elle a augmenté les valeurs de CAT et de PHT par rapport aux kiwis des plants témoins. La suppression de $30 \%$ de la surface foliaire n'a pas réduit le poids des fruits et le rendement des cultures ; elle a augmenté de $20 \%$ les valeurs de CAT et de PHT à la récolte. L'évolution après-récolte des valeurs de CAT et de PHT n'a pas varié en fonction des traitements. Discussion et conclusion. Les lianes de kiwis menées en pergola ont montré de bonnes performances en termes de rendement et de qualité des fruits lorsque l'élagage d'été a réduit l'indice de surface foliaire d'un facteur 3. Un élagage plus intense a entraîné une augmentation importante de la capacité antioxydante totale des fruits, mais il a réduit le poids des fruits et le rendement des cultures et retardé le ramollissement de la pulpe.

Italie / Actinidia deliciosa / pratique culturale / defolition / indice de surface foliaire / fruits / qualité / antioxydant / polyphénol 


\section{Introduction}

Maximizing sunlight interception and light distribution within the kiwifruit [Actinidia deliciosa (A. Chev.) Liang and Ferguson] canopy improves leaf photosynthetic rates, bud break and bud fertility, as well as crop yield, fruit quality (size and total soluble solid content) and post-harvest maintenance [1-3]. Summer pruning of kiwifruit vines, complementary to winter pruning, improves light distribution within the canopy, reduces the competition between the actively growing shoots and young developing fruitlets, and increases assimilate partitioning to the fruiting canes $[4,5]$. Fruit antioxidant components change with species, cultivar [6, 7], environmental conditions, orchard management, fruit ripening stage and length of postharvest fruit storage $[8,9]$; little is known about kiwifruit variability in terms of antioxidant capacity [10, 11]. Light distribution within the canopy can also play a role in fruit mineral composition [12] and total antioxidant capacity of fruits [13, 14], which in 'Hayward' kiwifruits is strongly due to their content of ascorbic acid and R-tocopherol, that account for $40 \%$ of the fruit antioxidant capacity [15]. Considering the nutritional value of kiwifruits and the importance that light interception may have in determining its variability, this study was undertaken to study the impact of summer pruning on fruit quality, including total antioxidant capacity (TAC) and total phenolic content (TPH), at fruit harvest time and 60 days after storage at $1{ }^{\circ} \mathrm{C}$.

\section{Materials and methods}

Our experiment was carried out over two years, 2009 and 2010, in a commercial kiwifruit orchard located in Southern Italy, in Rosarno (Reggio Calabria, Italy, 38²9' lat. N, $15^{\circ} 50^{\prime}$ long. E). Mature own-rooted vines of 'Hayward' kiwifruit $(4 \mathrm{~m} \times 4 \mathrm{~m}$ planting distances) were trained to a pergola system and managed according to local commercial practices. The staminate 'Tomuri' selection was used as a pollinizer (male:female ratio = 1:7). During winter dormancy, vines were pruned and had an equal number of canes
(18 \pm 2 canes per vine), with 18 to 20 buds per cane left on each vine. Four weeks after full bloom, early in July, two levels of summer pruning were executed: (i) removal of $30 \%$ of the leaf area; (ii) removal of $60 \%$ of the leaf area. Therefore, 30\% and 60\% of the shoots with indeterminate growth were removed.

These treatments were compared with the control (unpruned vines). According to Cruz-Castillo et al. [5], the "replacement cane zone" was the horizontal central area $1.0 \mathrm{~m}$ wide on either side of the vine leader, and the "fruiting zone" was the distal zone on either side of the replacement cane zone. Pruning involved the fruiting and vigorous vegetative shoots, particularly those with indeterminate growth, localized in both the fruiting zone and the replacement cane zone. However, some indeterminate shoots were preserved as replacement canes. Therefore, each treatment was characterized by a different thickness of the total vegetative mass. Treatments were compared in a randomized block design with three replicate plots of three vines per treatment (27 vines in total, 9 for each treatment). Summer pruning resulted in the removal of $20 \%$ of the fruit crop, in both pruning treatments. Any vegetative regrowth during the season was removed to avoid interference with the experiment. Photosynthetic Photon Flux Density (PPFD) was recorded along the four cardinal points per vine and per layer, using a LI-192 SB quantum meter (LI-COR, Lincoln, NE, USA). The instrument was placed in the middle of each of the two layers set to represent the bottom $\left(\mathrm{L}_{\mathrm{low}}\right)$ and the top $\left(\mathrm{L}_{\mathrm{up}}\right)$ canopy layers. $\mathrm{L}_{\mathrm{low}}$ and $\mathrm{L}_{\mathrm{up}}$ were $90 / 100 \mathrm{~cm}, 60 / 50 \mathrm{~cm}$ and $40 / 30 \mathrm{~cm}$ thick, respectively, in the control vines and when $30 \%$ and $60 \%$ of the canopy was removed.

Measurements were taken at noon, during every second week of July, September and October. At the end of the growing season, in October, the total leaf area per cane was calculated by multiplying the average leaf area, determined on a sample of 100 randomly collected leaves, with the number of leaves on each shoot chosen on four randomly selected canes. Leaf area was measured with a 3100 LI-COR area meter 
(LI-COR, Lincoln, NE, USA). The leaf area per vine was calculated by multiplying the average leaf area of a cane by the number of canes per vine. The Leaf Area Index (LAI) was calculated as the ratio between the vine leaf area and the ground area allotted to the vine. At harvest, during the first week of November, yield per cane and per shoot was recorded in the $\mathrm{L}_{\text {low }}$ and $\mathrm{L}_{\mathrm{up}}$ canopy layers and expressed in terms of total fresh weight and fruit count. The average fruit weight and leaf area per fruit was then calculated.

On each fruit of four canes per vine, fruit fresh weight was measured; flesh firmness, after skin removal, was determined with a digital penetrometer with an 8-mm tip (PCE-PTR200, Lucca, Italy); the total soluble solid content of the juice was determined with a PAL-1 digital refractometer (Atago Co. Ltd., Tokyo, Japan ), and total titratable acidity was measured with a HI 2210 digital $\mathrm{pH}$ meter (Hanna Instruments, Rhode Island, USA), and expressed as $\mathrm{g} \cdot \mathrm{L}^{-1}$ citric acid. Then, the average value was calculated for each parameter.

For each replicate, five fruits were placed in polyethylene bags and refrigerated at $-20{ }^{\circ} \mathrm{C}$ until the analyses of total antioxidant capacity and total phenolic content were performed on the fruit inner pericarp, separated from the seeds. Twenty g of pulp were taken from each fruit, with no epicarp. The same amount of fruit was stored, for 60 days, in cool chambers at $1{ }^{\circ} \mathrm{C}$ and $95 \%$ relative humidity, then placed at $20^{\circ} \mathrm{C}$ for 3 days to simulate shelf life. The total antioxidant capacity (TEAC) was determined, in fresh fruit and after storage, using the modified Trolox equivalent antioxidant capacity (TAC, mmol Trolox $\mathrm{Eq} \cdot \mathrm{g}^{-1}$ fresh weight) assay [16]. Total polyphenol content (TPH, mg gallic acid $\mathrm{Eq} \cdot \mathrm{L}^{-1}$ ) was determined using the Folin-Ciocalteu method [17]. The TAC assay included both the hydrophilic and lipophilic contributions [18] of the kiwifruit samples homogenized with an Ultra-Turrax blender. TEAC and TPH were analyzed separately using a KONTRON Uvikon 941 Plus spectrophotometer.

Data were analyzed using two-way ANOVA for mean comparisons, and standard errors were also calculated. Differences in plant development and production were calculated according to the Student-NewmanKeuls (SNK) test at $p \leq 0.05$. Differences in fruit quality and antioxidant content were calculated according to the least significant difference (LSD) test, at $p \leq 0.05$. Correlation analysis of TAC versus TPH was performed using STATISTICA (Statsoft Inc., Tulsa, OK, USA).

\section{Results}

Statistical analysis (not shown) revealed that the season did not affect any parameter, and no significant treatment $\times$ season interaction occurred. Hence, data for the two years were averaged. Photosynthetic Photon Flux density (PPFD) was 37\% lower in the bottom $\left(400 \mu \mathrm{mol} \cdot \mathrm{m}^{-2} \cdot \mathrm{s}^{-1}\right)$ than in the top $\left(630 \mu \mathrm{mol} \cdot \mathrm{m}^{-2} \cdot \mathrm{s}^{-1}\right)$ canopy layer of control vines. In the open field, Photosynthetic Photon Flux Density values between (1600 and 1800) $\mu \mathrm{mol} \cdot \mathrm{m}^{-2} \cdot \mathrm{s}^{-1}$ were recorded, accompanied by a high UV radiation.

Summer pruning resulted in a reduction in the Leaf Area Index (LAI) of 30\% and 60\% (table I). The leaf area ratio between the bottom and the top layers increased, from 0.40 in canes of the control vines to 0.70 in canes of vines with the highest pruning intensity, indicating that most pruning occurred in the top layer of the canopy (figure 1). The removal of $30 \%$ of vine leaf area increased intercepted Photosynthetic Photon Flux Density (PPFD) by 30\% (810 $\left.\mu \mathrm{mol} \cdot \mathrm{m}^{-2} \cdot \mathrm{s}^{-1}\right)$ and $70 \%\left(680 \mu \mathrm{mol} \cdot \mathrm{m}^{-2} \cdot \mathrm{s}^{-1}\right)$, respectively, in the top and bottom layers compared with control vines, while the removal of $60 \%$ of vine leaf area almost doubled PPFD in the bottom canopy layer $\left(770 \mu \mathrm{mol} \cdot \mathrm{m}^{-2} \cdot \mathrm{s}^{-1}\right)$ and increased PPFD by $50 \%$ in the top canopy layer $(910 \mu \mathrm{mol}$. $\mathrm{m}^{-2} \cdot \mathrm{s}^{-1}$ ). Ultimately, when $30 \%$ or $60 \%$ of canopy leaf area was removed, the average PPFD within the canopy significantly increased, and the bottom canopy layer received 15\% less PPFD than the top canopy layer. These large differences in the LAI and PPFD resulted in significant changes in fruit weight, firmness and titratable acidity, as well as in their antioxidant value, expressed by total antioxidant capacity (TAC) and total 


\section{G. Gullo et al.}

Table I.

Fruit count, leaf area per fruit, Leaf Area Index (LAI) and yield measured in vines of Actinidia deliciosa, cv. Hayward, subjected to summer pruning (removal of $-30 \%$ and $-60 \%$ of leaf area) and unpruned trees (control).

$\begin{array}{lccr}\text { Kiwi treatment } & \begin{array}{c}\text { Number of fruit } \\ \text { per plant }{ }^{1}\end{array} & \begin{array}{c}\text { Leaf area } \cdot \text { fruit }^{-1} \cdot \mathrm{m}^{-2} \\ \text { Yield }\end{array} & \begin{array}{c}\text { Leaf Area Index } \\ \left(\mathrm{m}^{2} \cdot \mathrm{m}^{-2}\right)\end{array} \\ \text { Control } & 473 \pm 10.2 & 0.17 \pm 0.010 \mathrm{a} & 5.0 \pm 0.08 \mathrm{a} \\ -30 \% \text { of leaf area } & 468 \pm 11.2 & 0.12 \pm 0.008 \mathrm{~b} & 3.6 \pm 0.12 \mathrm{~b} \\ -60 \% \text { of leaf area } & 445 \pm 9.2 & 0.06 \pm 0.009 \mathrm{c} & 1.9 \pm 0.09 \mathrm{c}\end{array}$

Data are reported as means $(2009-2010) \pm$ standard error $(n=18)$.

Comparing treatments and control in each column, different letters indicate significant differences at $p \leq 0.05$.

${ }^{1}$ Not significant.

${ }^{2} \mathrm{LAl}=[($ vine leaf area) $/$ (ground area allotted to the vine) $]$.

\section{Figure 1.}

Leaf area per cane in the bottom and top layers of the canopy of vines of Actinidia deliciosa, cv. Hayward, trained to a pergola system, in relation to three summer pruning treatments (control with no pruning, removal of $30 \%$ of leaf area and removal of $60 \%$ of leaf area) applied four weeks after bloom.

Data are reported as means (2009-2010). Different letters indicate significant differences at $P \leq 0.05 ;$ ns $=$ not significant Bars represent the standard error $(n=36 \times 2$ years $=72)$.

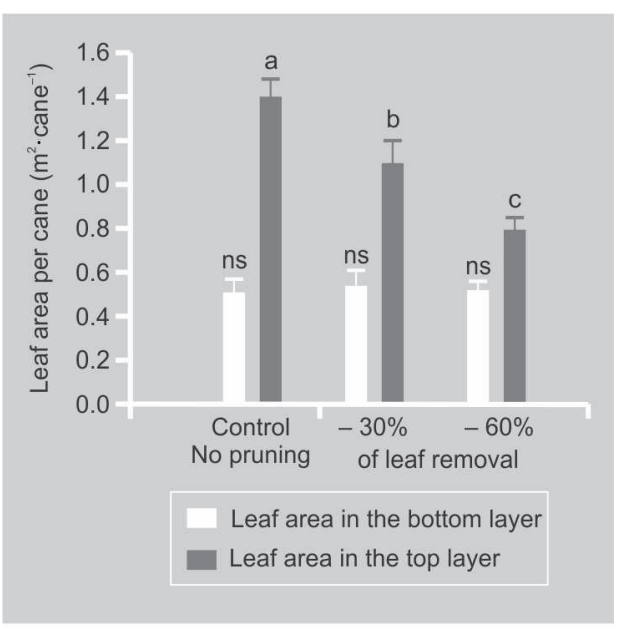

polyphenol (TPH) fruit content. The number of fruits per plant did not change with treatment, whereas the unit leaf area per fruit decreased by $29 \%$ when $30 \%$ of leaf area was removed and $64 \%$ when $60 \%$ of leaf area was removed, while crop yield significantly decreased by $20 \%$, only at $-60 \%$ leaf area, almost consistently with the reduction $(15 \%)$ in fruit fresh and dry weight (tables I, II).

Fruit firmness and titratable acidity did not change with canopy layer, and significantly increased at the highest pruning intensity (table III). Total soluble solids (TSS) did not change significantly with pruning, but was significantly lower in fruits of the bottom canopy layer in the control rather than in the pruned vines (table III). No differences in fruit TAC and TPH occurred within the canopy of control vines (figures 2, 3), while fruit TAC significantly increased, at harvest, almost linearly with pruning intensity in both canopy layers

\section{Table II.}

Fruit fresh weight, dry weight and dry matter content in fruit of the bottom and top layers of the canopy of Actinidia deliciosa, cv. Hayward, vines trained to a pergola system, in relation to summer pruning (removal of $-30 \%$ and $-60 \%$ of leaf area) and unpruned trees (control treatment) applied four weeks after bloom.

\begin{tabular}{|c|c|c|c|c|c|c|}
\hline \multirow[t]{2}{*}{$\begin{array}{l}\text { Kiwi } \\
\text { treatment }\end{array}$} & \multicolumn{2}{|c|}{$\begin{array}{c}\text { Fresh weight } \\
\text { (g) }\end{array}$} & \multicolumn{2}{|c|}{$\begin{array}{l}\text { Dry weight } \\
\text { (g) }\end{array}$} & \multicolumn{2}{|c|}{$\begin{array}{c}\text { Dry matter content }{ }^{1} \\
(\%)\end{array}$} \\
\hline & Bottom layer & Top layer & Bottom layer & Top layer & Bottom layer & Top layer \\
\hline Control & $106.2 \pm 5.5 a$ & $105.5 \pm 6.5 a$ & $16.29 \pm 1.08 a$ & $17.71 \pm 1.24 \mathrm{a}$ & $15.4 \pm 0.68 b$ & $17.03 \pm 0.89 a$ \\
\hline $\begin{array}{l}-30 \% \text { of } \\
\text { leaf area }\end{array}$ & $106.8 \pm 3.8 \mathrm{a}$ & $104.5 \pm 5.1 \mathrm{a}$ & $18.20 \pm 1.10 a$ & $18.48 \pm 1.08 a$ & $17.4 \pm 0.54 \mathrm{a}$ & $17.50 \pm 0.19 a$ \\
\hline $\begin{array}{l}-60 \% \text { of } \\
\text { leaf area }\end{array}$ & $90.3 \pm 2.8 b$ & $89.8 \pm 3.1 \mathrm{~b}$ & $13.69 \pm 1.01 b$ & $13.40 \pm 1.02 b$ & $15.5 \pm 0.54 b$ & $15.05 \pm 0.56 b$ \\
\hline
\end{tabular}




\section{Table III.}

Titratable acidity, flesh firmness and total soluble solid content in fruit of the bottom and top layers of the canopy of Actinidia deliciosa, cv. Hayward, vines trained to a pergola system, in relation to summer pruning (removal of $-30 \%$ and $-60 \%$ of leaf area) and unpruned trees (control treatment) applied four weeks after bloom.

\begin{tabular}{|c|c|c|c|c|c|c|}
\hline \multirow[t]{2}{*}{ Kiwi treatment } & \multicolumn{2}{|c|}{$\begin{array}{c}\text { Titratable acidity } \\
\qquad\left(\mathrm{g} \cdot \mathrm{L}^{-1}\right)\end{array}$} & \multicolumn{2}{|c|}{$\begin{array}{l}\text { Flesh firmness } \\
\left(\mathrm{N} \cdot \mathrm{cm}^{-2}\right)\end{array}$} & \multicolumn{2}{|c|}{$\begin{array}{l}\text { Total soluble solid content }{ }^{1} \\
\text { ( }{ }^{\circ} \text { Brix) }\end{array}$} \\
\hline & Bottom layer & Top layer & Bottom layer & Top layer & Bottom layer & Top layer \\
\hline Control & $8.2 \pm 0.2 b$ & $8.2 \pm 0.2 b$ & $105.9 \pm 2.9 b$ & $105.9 \pm 3.9 b$ & $6.0 \pm 0.2 b$ & $7.7 \pm 0.5 a$ \\
\hline$-30 \%$ of leaf area & $8.1 \pm 0.3 b$ & $8.1 \pm 0.3 b$ & $106.9 \pm 3.9 b$ & $106.9 \pm 2.8 b$ & $6.8 \pm 0.2 \mathrm{a}$ & $7.1 \pm 0.4 \mathrm{a}$ \\
\hline$-60 \%$ of leaf area & $9.5 \pm 0.3 a$ & $9.5 \pm 0.3 a$ & $117.7 \pm 5.0 \mathrm{a}$ & $112.8 \pm 2.1 \mathrm{a}$ & $6.9 \pm 0.2 \mathrm{a}$ & $7.2 \pm 0.3 a$ \\
\hline
\end{tabular}

(figure 2). Significant differences between TAC values for fruit of the top and bottom canopy layers occurred only in pruned vines and TAC reached the highest values with the highest pruning rate in the top canopy layer (figure 2). TPH increased with pruning, but significant differences between the top and bottom layers occurred only when 30\% leaf area was removed; further pruning did not account for any significant increase in TPH in fruits of the two layers compared with the top canopy layer of the plants in which 30\% of leaf area was removed (figure 3). The correlation (data not shown) between polyphenol content and total antioxidant capacity was higher in the top, sunny, layer $(r=0.81)$ than in the bottom, shady one $(r=$ 0.48). The Pearson's coefficient decreased with pruning intensity, sharply in the top layer (table $I V$ ). Sixty days after storage, TAC (figure 4a) and TPH (figure 4b) increased by $20 \%$ in all treatments.

\section{Discussion}

Optimization of the Leaf Area Index in kiwifruit vines is, generally, achieved through winter pruning rather than summer pruning, with optimal values, for fruit quality, ranging from 3 to 3.5 [2]. Lai et al. [19] showed that kiwifruit size was not reduced at low leaf-fruit ratios (less than 2:1) because assimilate translocation from other parts of the vine could meet any shortage in the local supply of carbohydrates to the fruiting

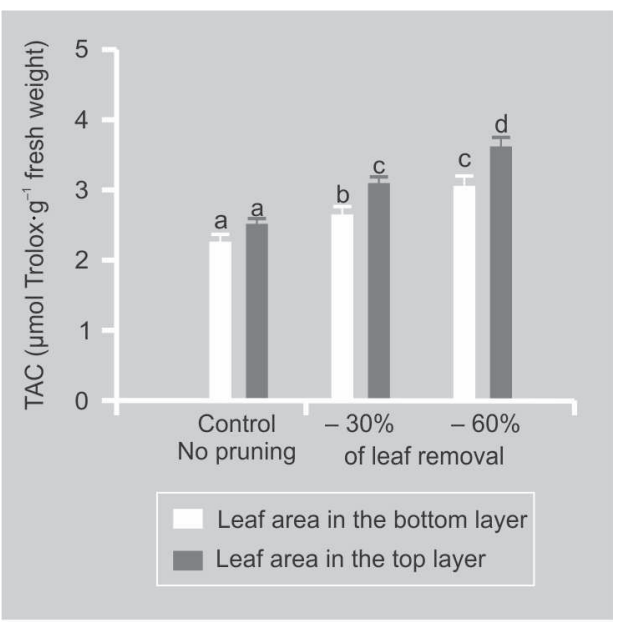

Figure 2.

TotalAntioxidantCapacity(TAC) of fruits located in the bottom and top layers of the canopy of vines of Actinidia deliciosa, cv. Hayward, trained to a pergola system, in relation to three summer pruning treatments (control with no pruning, removal of $30 \%$ of leaf area and removal of $60 \%$ of leaf area) applied four weeks after bloom. Data are reported as means (2009-2010). Different letters indicate significant differences at $p \leq 0.05$. Bars represent the standard error $(n=15 \times$ 2 years $=30$ ).

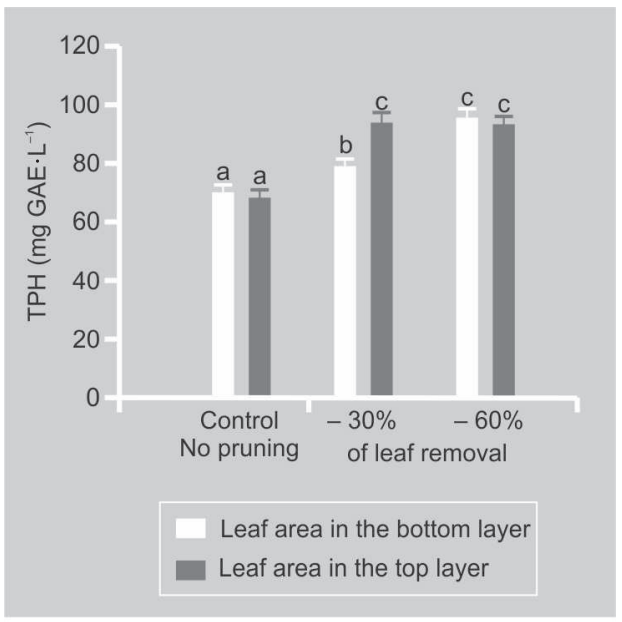

laterals. In this work, large differences in the LAI and PPFD resulted in significant changes in fruit weight, firmness and titratable

\section{Figure 3.}

Fruit Total Polyphenols (TPH) of fruits located in the bottom and top layers of the canopy of vines of Actinidia deliciosa, cv. Hayward, trained to a pergola system, in relation to three summer pruning treatments (control with no pruning, removal of $30 \%$ of leaf area and removal of $60 \%$ of leaf area) applied four weeks after bloom.

Data are reported as means (2009-2010). Different letters indicate significant differences at $p \leq 0.05$. Bars represent the standard error $(n=15 \times$ 2 years $=30$ ). 


\section{G. Gullo et al.}

\section{Table IV. \\ Pearson's coefficient between Total Antioxidant Capacity (TAC) and Total Polyphenol Content (TPH) in fruit of the bottom and top layers of the canopy of Actinidia deliciosa, cv. Hayward, vines trained to a pergola system, in relation to summer pruning (removal of $-30 \%$ and $-60 \%$ of leaf area) and unpruned trees (control treatment) applied four weeks after bloom.}

\begin{tabular}{lcc} 
Kiwi treatment & Bottom layer & Top layer \\
Control & $0.78 \mathrm{a}$ & $0.89 \mathrm{a}$ \\
$-30 \%$ of leaf area & $0.65 \mathrm{~b}$ & $0.42 \mathrm{c}$ \\
$-60 \%$ of leaf area & $0.60 \mathrm{~b}$ & $0.37 \mathrm{c}$ \\
\hline Data are reported as means (2009-2010) \pm standard error $(n=15 \times 2$ years $=30)$. \\
For each parameter, means accompanied by different letters are significantly different at $p \leq 0.05$.
\end{tabular}

\section{Figure 4.}

Total Antioxidant Capacity (TAC) (a) and Fruit Total Polyphenols (TPH) (b) after storage at $1{ }^{\circ} \mathrm{C}$ for two months of fruit grown in the bottom and top layers of the canopy of vines of Actinidia deliciosa, cv. Hayward, in relation to three summer pruning treatments (control with no pruning, removal of $30 \%$ of leaf area and removal of $60 \%$ of leaf area) applied four weeks after bloom.

Data are reported as means (2009-2010). For each canopy layer, different letters indicate significant differences at $p \leq 0.05$. Bars represent the standard error $(n=15 \times$ 2 years $=30$ ).

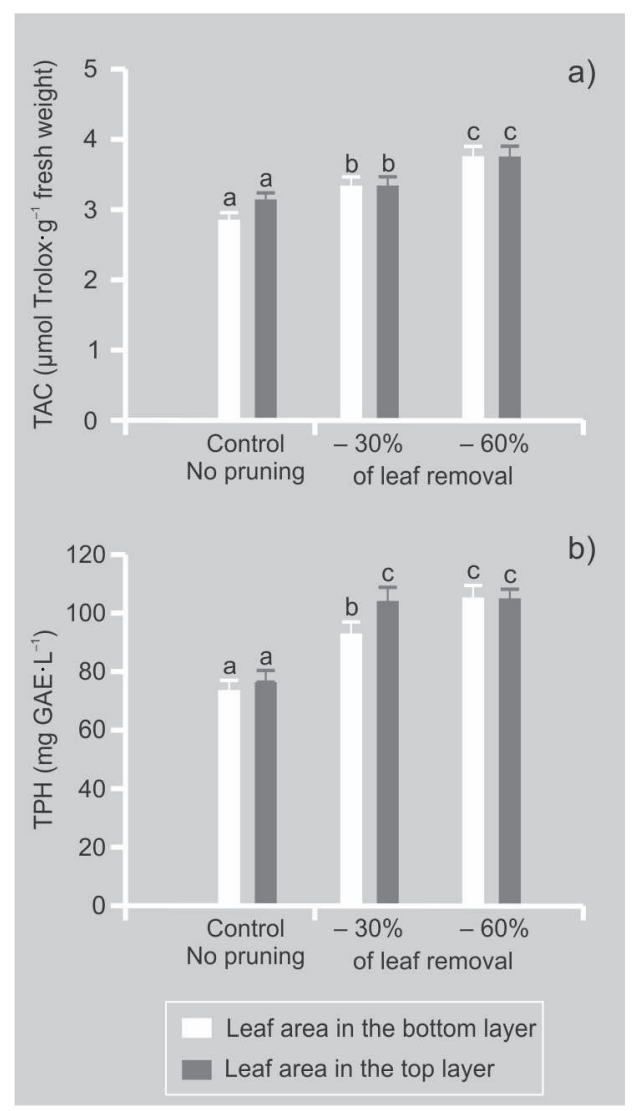

acidity, as well as in their nutraceutical value, expressed by fruit TAC and TPH content.

The TAC is affected by several variables, genetic and environmental [20]. Light significantly increased the accumulation of phenols in the fruit [21].
A LAI value of 1.9 resulted in a significant increase in the fruit:leaf ratio, and reduced fruit size, with no effect on fruit TSS.

Differences in TSS occurred only in unpruned vines, when the top and the bottom layers greatly differed in terms of light interception. Tombesi et al. [22] reported a reduction of fruit size and TSS along with a reduction of the LAI, as a result of a source:sink imbalance rather than because of differences in light environments within the canopy. Consistently with our findings, Tombesi et al. [3] reported an increase in flesh firmness at low leaf:fruit ratios. TPH increased in both canopy layers with pruning intensity but its role in determining TAC apparently decreased, as shown by the decrease in the Pearson's coefficient. This may be related to the major role of components other than TPH, such as ascorbic acid, that usually increases largely along with PPF [23]. Summer pruning made it possible to achieve, in fruit located in the upper canopy layer of pruned kiwifruit vines, much higher TAC values than those reported for peach, apple and apricot [18], even higher than those previously reported for this species [10]. However, the removal of $60 \%$ leaf area reduced fruit weight and resulted in a significant decrease in vine crop yield.

Cold storage conditions significantly increased TAC and total phenol content; this can be attributed to changes occurring in phenol metabolism during storage, as well as the increase in phenylalanine ammonia lyase (PAL). Considering that ascorbic acid content usually decreases during storage, 
TPH plays a consistent role in determining fruit antioxidant capacity at this stage.

In conclusion, pergola-trained kiwifruit vines showed good performances in terms of crop yield and fruit quality when summer pruning reduced the LAI to 3 . Further pruning resulted in a significant increase in fruit TAC, but greatly reduced fruit size and crop yield, and delayed softening of pulp.

\section{References}

[1] Grant J.A., Ryugo K., Influence of withincanopy shading on fruit size, shoot growth, and return bloom in kiwifruit, J. Am. Soc. Hortic. Sci. 109 (6) (1984) 799-802.

[2] Patterson K.J., Currie M.B., Optimising kiwifruit vine performance for high productivity and superior fruit taste, Acta Hortic. 913 (2011) 257-268.

[3] Tombesi A., Antognozzi E., Paliotti A., Influence of light exposure on characteristics and storage life of kiwifruit, N. Z. J. Crop Hortic. Sci. 21 (1993) 87-92.

[4] Tombesi A., Antognozzi E., Palliotti A., Influence of assimilate availability on translocation and sink strength in kiwifruit, N. Z. J. Crop Hortic. Sci. 21 (1993) 177-182.

[5] Cruz-Castillo J.G., Woolley D.J., Famiani F., Effects of defoliation on fruit growth, carbohydrate reserves and subsequent flowering of 'Hayward' kiwifruit vines, Sci. Hortic. 125 (2010) 579-583.

[6] Wang H., Cao G., Prior R.L., Total antioxidant capacity of fruits, J. Agric. Food Chem 44 (1996) 701-705.

[7] Hegedús A., Engel R., Abrankó L., Balogh E., Blázovics A., Hermán R., Halász J., Ercisli S., Pedryc A., Stefanovits-Bányai E., Antioxidant and antiradical capacities in apricot (Prunus armeniaca L.) fruits: Variations from genotypes, years, and analytical methods, $\mathrm{J}$. Food Sci. 75 (9) (2010) C722-C730.

[8] Ferreyra R.M, Vina S.Z., Mugridge A., Chaves A.R., Growth and ripening season effects on antioxidant capacity of strawberry cultivar Selva, Sci. Hortic. 112 (2007) 27-32.

[9] Duda-Chodak A., Tarko T., Tuszyński T., Antioxidant activity of apples - an impact of maturity stage and fruit part, Acta Sci. Pol. Technol. Aliment. 10 (4) (2011) 443-454.

[10] Du G., Li M., Ma F., Liang D., Antioxidant capacity and the relationship with polyphenol and vitamin $\mathrm{C}$ in Actinidia fruits, Food Chem. 113 (2009) 557-562.

[11] Fiorentino A., d'Abrosca B., Pacifico S., Identification and assessment of antioxidant capacity of phytochemicals from kiwi fruits, J. Agric. Food Chem. 57 (2009) 4148-4155.

[12] Montanaro G., Dichio B., Xiloyannis C., Celano G., Light influences transpiration and calcium accumulation in fruit of kiwifruit plants (Actinidia deliciosa var. deliciosa), Plant Sci. 170 (2006) 520-527.

[13] Motisi A., Gullo G., Zappia R., Mafrica R., Dattola A., Malara T., Diamanti J., Mezzetti B., Variation of some qualitative parameters in fruit of "Rich May" peach trees in two graft combinations, in: Di Vaio C., Daminano C., Fideghelli C. (Eds.), Proc. 6th Ntl. Conf. Southern peach, Caserta, Italy, 2008, pp. 408413.

[14] Remorini D., Tavarini S., Degl'Innocenti E., Loreti F., Massai R., Guidi L., Effect of rootstocks and harvesting time on the nutritional quality of peel and flesh of peach fruits, Food Chem. 110 (2008) 361-367.

[15] Collins B.H., Horska A., Hotten P.M., Riddoch C., Collins A.R., Kiwifruit protects against oxidative DNA damage in human cells and in vitro, Nutr. Cancer 39 (2001) 148-153.

[16] Re R., Pellegrini N., Proteggente A., Pannala A., Yang M., Rice-Evans C., Antioxidant activity applying an improved ABTS radical cation decolorizing assay, Free Radic. Biol. Med. 26 (1999) 1231-1237.

[17] Slinkard K., Singleton V.L., Total phenol analysis: automation and comparison with manual methods, Am. J. Enol. Vitic. (1977) 28-49.

[18] Scalzo J., Politi A., Pellegrini N., Mezzetti B., Battino M., Plant genotype affects total antioxidant capacity and phenolic contents in fruit, Nutr. 21 (2005) 207-213.

[19] Lai R., Woolley D.J., Lawes G.S., Effect of leaf to fruit ratio on fruit growth of kiwifruit (Actinidia deliciosa), Sci. Hortic. 39 (1989) 247-255.

[20] Howard L.R., Clark J.R., Brownmiller C., Antioxidant capacity and phenolic content in blueberries as affected by genotype and growing season, J. Sci. Food Agric. 83 (12) (2003) 1238-1247.

[21] Montanaro G.,Treutter D., Xiloyannis C., Phenolic compounds in young developing kiwifruit in relation to light exposure: implications for fruit calcium accumulation, J. Plant Interact. 2 (1) (2007) 63-69. 
[22] Tombesi A., Antognozzi E., Palliotti A., Optimum leaf area index in T-bar trained kiwifruit vines, J. Hortic. Sci. 69 (1994) 339350.
[23] Gil M.I., Aguayo E., Kader A.A., Quality changes and nutrient retention in fresh-cut versus whole fruits during storage, J. Agric. Food Chem. 54 (2006) 4284-4296.

\section{Efecto de la poda de verano en determinados parámetros que determinan la calidad de los kiwis de la variedad Hayward.}

Resumen - Introducción. Nuestro estudio se encaminó a analizar los efectos, en determinados parámetros de la calidad de los kiwis, de los distintos niveles de disponibilidad de luz en el microentorno de las frutas. Los distintos niveles de disponibilidad de luz se debieron a una poda de verano más o menos intensiva. Material y métodos. Se aplicaron dos niveles de poda de verano: una supresión del 30\% o el 60\% de la superficie foliar de la copa. Dichos tratamientos se compararon con un tratamiento de control de lianas sin podar. Se distinguieron dos estratos en las copas (superior e inferior) para cada uno de los dos tratamientos y para las lianas de control. En el momento de la cosecha, se registró el rendimiento por caña y por tallo en cada uno de los dos estratos de las copas; se midieron el peso en fresco de las frutas, la firmeza de la pulpa, el contenido total en sólidos solubles y la acidez valorable. La capacidad antioxidante total (CAT) y los polifenoles totales (PHT) de las frutas se determinaron en el momento de la recogida de los kiwis y tras 60 días de almacenamiento a $1^{\circ} \mathrm{C}$; estos parámetros se estudiaron en función de su posición en la copa (estrato) y del tratamiento de poda aplicado a la liana. Resultados. La supresión del $60 \%$ de la superficie foliar de la cubierta indujo a una acidez valorable superior y a una pulpa más firme en el momento de la recogida de los kiwis; redujo el peso de las frutas y el rendimiento de la cosecha, pero aumentó los valores de CAT y de PHT con respecto a los kiwis de las plantas de control. La supresión del 30\% de la superficie foliar no redujo el peso de las frutas ni el rendimiento de la cosecha, y aumentó en un $20 \%$ los valores de CAT y de PHT en el momento de la recogida. La evolución tras la cosecha de los valores de CAT y de PHT no varió en función del tratamiento. Discusión y conclusión. Las lianas de kiwis colocadas en pérgolas mostraron resultados óptimos en términos de rendimiento y de calidad de las frutas, mientras que la poda de verano redujo el índice de superficie foliar en un factor 3. Una poda más intensiva implicó un aumento importante de la capacidad antioxidante total de las frutas, pero redujo el peso de la misma y el rendimiento de las cosechas, además de retrasar el reblandecimiento de la pulpa.

Italia / Actinidia deliciosa / cultivo / defoliación / indice de superficie foliar / frutos / calidad / antioxidantes / polyfenoles 